\title{
Regional Human Rights Bodies (2020)
}

\author{
Flavia Zorzi Giustiniani*
}

\section{Introduction}

In the course of $202 \mathrm{O}$, the activities of the different regional human rights systems were heavily affected, and indeed monopolised, by the Coronavirus disease 2019 (COVID-19), which as is known unleashed a veritable and unprecedented global disaster - namely a health crisis of universal dimension (pandemic). ${ }^{1}$

In particular, most of the operational activities of human rights bodies were reduced, postponed or cancelled, and when they were at last resumed, this generally happened in a virtual modality. Regional bodies also extended or suspended deadlines for pending complaints. Specifically, the computation of time limits was suspended by the African Court on Human and Peoples' Rights from 1 May to 31 July $2 \mathrm{O}^{2} \mathrm{O}^{2}$ and by the Inter-American Court of Human Rights from 17 March to 20 May 2020. ${ }^{3}$ The European Court of Human Rights extended the six-month time-limit for lodging an application ex Article 35 ECHR from 16 March until 15 June 2020 inclusive and the time-limits which

* Associate Professor of European Union Law, Link Campus University.

1 Covid-19 was officially declared as a 'public health emergency of international concern' by the wHO's Emergency Committee on 30 January 2020 (see wHO, 'Statement on the second meeting of the International Health Regulations (2005) Emergency Committee regarding the outbreak of novel coronavirus (2019-nCoV)' (30 January 2020) available at <https:// www.who.int/news/item/3o-01-2020-statement-on-the-second-meeting-of-the-inter national-health-regulations-(2005)-emergency-committee-regarding-the-outbreak-of -novel-coronavirus-(2019-ncov) > last accessed (as any subsequent URL) on 6 June 2021, and finally as a pandemic on 11 March 2020 (see WHO, 'WHO Director-General's opening remarks at the media briefing on COVID-19 - 11 March 2020', available at <https://www.who.int/dg/ speeches/detail/who-director-general-s-opening-remarks-at-the-media-briefing-on-covid -19-11-march-2020>.

2 See African Court on Human and Peoples' Rights, 'Suspension of time limits due to the measures taken in response to Covid-19 - Press Release' (22 May 2020), <http://www.african-court .org/wpafc/suspension-of-time-limits-due-to-the-measures-taken-in-response-to-covid-19/>.

3 See Inter-American Court of Human Rights, 'Inter-American Court of Human Rights resumes accounting of all deadlines' (2O May 2020) <https://www.corteidh.or.cr/docs/comunicados/ cp_37_202O_eng.pdf>. 
had been allotted in pending proceedings for a total of three months from 16 March 2020. ${ }^{4}$

Apart from COVID-19, in 202O, there were no regional developments regarding specifically disaster-related issues. However, some important developments in this period concerned the "other" global ongoing crisis, i.e. climate change, and notably the applicability in this respect of the ECHR.

\section{Developments within the African Human Rights System}

The African Commission was the first human rights treaty body in the world to issue a statement on the COVID-19 crisis on 28 February 2020. ${ }^{5}$ Expressing its concern on the risks deriving from the virus for the health and safety of African peoples, in its initial statement, the Commission recalled relevant provisions of the African Charter, notably the rights to life (Article 4), access to information (Article 9) and health (Article 16). It then urged States to take 'preventive measures to secure the health, safety and life of peoples of the States Parties to the African Charter. ${ }^{6}$ The statement, inter alia, emphasised the importance that the measures taken 'include vulnerable and marginalized groups, are gender-sensitive, child-friendly and disability-sensitive,, ${ }^{7}$ that health workers are adequately provided with necessary equipment and supplies and that 'restrictions imposed on public health grounds are lawful, respect human and peoples' rights, are necessary and proportional.' 8

A month later, on 24 March, the Commission released another statement in order to guide States in the provision of a human rights-based effective response to CoviD-19. ${ }^{9}$ Alarmed by the growing spread of the novel virus across the continent and by the inadequacy of national health systems, the Commission reaffirmed 'the imperative of putting in place a well thought out

4 This extension did not apply to the three-month period under Article 43 of the Convention for requesting the referral of a case to the Grand Chamber. See European Court of Human Rights, 'Extension of exceptional measures at the European Court of Human Rights - Press Release', ECHR 108 (2020) (9 April 202O).

5 See African Commission on Human and Peoples' Rights (AChPR), 'Press Statement on human rights based effective response to the novel covid-19 virus in Africa', Banjul (28 February 2020).

6 Ibid., fourth introductory paragraph.

7 Ibid., para. 6.

8 Ibid., para. 8.

9 See ACHPR, 'Press Statement on human rights based effective response to the novel covid19 virus in Africa', Banjul (24 March 2020). 
public health emergency plan:10 This statement also addresses the issue of migration measures and lockdowns adopted at a national level to prevent and contain the pandemic and 'recognizes the legitimacy of the concerns regarding the socio-economic impacts' of some of these measures. ${ }^{11}$ As a consequence, it stresses the need that such measures be 'accompanied by contextually tailored policy measures for mitigating the adverse impacts, particularly on the most vulnerable section of society'.12

Furthermore, in the first part of the year, the Commission adopted numerous guidelines focusing on various COVID-19-related issues such as the holding of elections, access to the internet and the virus' impact on economic, social and cultural rights in general and on specific groups such as mine workers and mining affected communities, Human Rights Defenders (HRDs), women, indigenous peoples and prisoners. ${ }^{13}$

Later on, during its 66th ordinary session from 13 July to 7 August 2020, that on account of the pandemic for the first time ever was held online, the Commission adopted two thematic resolutions related to Covid-19: Resolution 447 on upholding human rights during situations of emergency and in other exceptional circumstances ${ }^{14}$ and Resolution 449 on Human and Peoples' Rights as the central pillar of a successful response to Covid-19 and recovery from its socio-political impacts. Notably, in the first Resolution, the Commission tasked its Focal Point on Human Rights in Conflict Situations in Africa to 'develop a normative framework in the form of Guidelines on adhering to human and peoples' rights standards under the African Charter when declaring states of emergency or disaster'.15 In Resolution 449, on the other hand, the Commission inter alia urged States parties to ensure mechanisms for accountability and access to justice in the face of possible violations of human rights resulting from COVID-19 response measures ${ }^{16}$ and to ' $[\mathrm{u}]$ rgently reorganize their annual budgets in order to apportion 15 percent to the health sector as contained in the Abuja Declaration as one of the measures to improve the state of health systems to deal with future pandemics.'. ${ }^{17}$

\footnotetext{
$10 \quad$ Ibid., para. 9 .

11 Ibid., eleventh introductory paragraph.

12 Ibid.

13 See $<$ https://www.achpr.org/pressrelease/index > .

14 See ACHPR, 'Resolution on upholding human rights during situations of emergency and in other exceptional circumstances' ACH PR/Res. 447 (LXVI) 2020 (7 August 2020).

15 Ibid., para. 1.

16 See ACHPR, 'Resolution on Human and Peoples' Rights as central pillar of successful response to COVID-19 and recovery from its socio-political impacts', ACHPR/Res. 449 (LXVI) 2020 (7 August 2020).

17 Ibid., para. 11 .
} 
Finally, another relevant development in standard-setting related to Covid-19 is attributable to the African Committee of Experts on the Rights and Welfare of the Child (ACERWC). Established in 2001 as an organ of the African Union, the Committee's main tasks are to collect information, interpret provisions of the African Charter on the Rights and Welfare of the Child and monitor its implementation, give recommendations to governments for working with child rights organisations, consider individual complaints about violations of children's rights, and investigate measures adopted by Member States to implement the Charter. On 8 April, the Committee issued a Guiding Note concerning the pandemic's implications on children's rights and welfare. ${ }^{18}$ The Note recommended Member States to integrate some child protection measures in their responses to CoviD-19, namely: (i) Establish child friendly information and communication procedures; (ii) Establish child friendly quarantine procedures and environment; (iii) Ensure every child's right to education; (iv) Ensure continued provisions of essential services which are crucial to life, survival and development of children; (v) Ensure that children enjoy their right to parental care and protection in terms of the Article 19 of the African Children's Charter; and (vi) Tailor responses in line with the special vulnerabilities of the concerned group of children. ${ }^{19}$ It then encouraged Member States, 'with a view to count the cost on children and identify the practical steps which can be taken to mitigate on the losses', to make a national assessment on the virus' outbreak and its impact on the rights and welfare of children. ${ }^{20}$

\section{Developments within the Inter-American System}

In 2020, the Inter-American Commission on Human Rights (IACH R) adopted four resolutions, two of which concerned the CoviD-19 pandemic: Resolution 1/2020 on 'Pandemic and Human Rights in the Americas'21 and Resolution 4/2020 on 'Human Rights of Persons with CoviD-19'.22 These resolutions constitute the main achievement accomplished by the Rapid and

18 ACERWC, 'COVID-19 and its implications on children's rights and welfare: Guiding Note to member states of the African Union' <https://www.acerwc.africa/wp-content/ uploads/2020/o4/Guiding-Note-on-Child-Protection-during-COVD-19_English-1.pdf>.

19 Ibid., 2.

$20 \quad$ Ibid., 7.

21 See IACHR, Resolution No. 1/2020 - 'Pandemic and Human Rights in the Americas' (10 April 202O).

22 See IACHR, Resolution No. 4/2020 - 'Human Rights of Persons with COVID-19' (27 July 2020). 
Integrated Response Coordination Units (SACROI) on COVID-19. Established on 27 March 2020, SACROI COVID-19 is the first thematic unit of this kind and is designed to strengthen IACHR's capabilities for protecting and defending human rights, especially the right to health and other economic, social, cultural and environmental rights, in the context of the pandemic. ${ }^{23}$

Resolution 1/2020, prepared with the support of the Special Rapporteurships on Economic, Social, Cultural, and Environmental Rights and for Freedom of Expression, and the Thematic Rapporteurships was released on 10 April and established standards and recommendations to guide States ensuring full respect for human rights during the pandemic. Importantly, the resolution clarifies how states of emergencies apply in case of pandemics or other health emergencies and indicates guidelines that States parties should follow in such situations. Warning States on the risk of excessive measures, the Inter-American Commission recommended that all restrictions and suspensions be based 'on the best scientific evidence. ${ }^{24}$ The resolution then accords considerable attention to especially vulnerable groups such as older persons, persons deprived of liberty, women, indigenous peoples, persons in human mobility, children and adolescents, LG BTI persons, Afro-descendant persons, and persons with disabilities. ${ }^{25}$ In this respect, the Commission recommended that the adoption of emergency measures to address the pandemic be accompanied by an intersectional approach and that States pay particular attention to the needs and the differential impact of such measures on the human rights of those groups that have historically suffered discrimination or that are especially vulnerable. ${ }^{26}$ Regarding women, the Commission manifested its concern for the increase of domestic violence that followed the various stay at home orders adopted at the national level. Accordingly, it called on States to apply a gender perspective in all responses to contain the pandemic. ${ }^{27}$

Resolution 4/2020, entitled 'Human Rights of Persons with CoviD-19', was instead adopted on 27 July 2020 and sets out guidelines that States should follow in order to respect and protect the rights of people with covid-19. Within this broad notion, the Commission intends to embrace people who are thought to have been infected by the virus, people who are in both the pre-symptomatic and symptomatic phases (be they mild, moderate, severe, or critical cases), as well as those who are asymptomatic, those undergoing

23 See IACHR, 'IACHR Implements Rapid and Integrated Response Coordination Unit for COVID-19 Pandemic Crisis Management', Press Release (28 March 2020).

24 See IACHR, Resolution No. 1/2020 cit., para. 27.

25 Ibid., III, 6.

26 Ibid.

27 Ibid., para. 49 . 
medical research tests, and those who have been killed by the pandemic, as well as their families and/or caregivers. ${ }^{28}$ The Resolution's objective is to establish the 'Inter-American Guidelines regarding the Human Rights of Persons with COVID-19', which were drafted by the SACROI COVID-19 with the support of the Office of the Special Rapporteur on Economic, Social, Cultural, and Environmental Rights and expert contributions from the Office of the Special Rapporteur on Freedom of Expression.

\section{Developments within the Council of Europe}

Among the measures adopted within the Council of Europe system, a first important development for our purposes is the Statement of principles relating to the treatment of persons deprived of their liberty. The Statement was released on 20 March 2020 by the European Committee for the Prevention of Torture and Inhuman or Degrading Treatment or Punishment (СРT), ${ }^{29}$ which is the non-judicial mechanism set up to monitor the implementation of the related European Convention of 1987. The document contains ten recommendations addressed to all Member States' authorities in order to remind them, in such an emergency period, of the absolute nature of the prohibition of torture and inhuman or degrading treatment ex Article 3 of the Convention. Persons deprived of their liberty are at higher risk from CoviD-19 given the overcrowding, the poor conditions of detention and scarce ventilation that characterise many prisons and the significant number of prisoners in vulnerable health situations. ${ }^{30}$ Moreover, as was underlined by the World Health Organization (wHo), efforts to control the pandemic in the broader community are likely to fail if strong measures are not taken in places of detention. ${ }^{31}$

In the CPT's view, while the pandemic has created extraordinary challenges for the Member States of the Council of Europe, protective measures to combat COVID-19 must never result in inhuman or degrading treatment of persons deprived of their liberty. Its recommendations concern not just prisons but more broadly places of deprivation of liberty, such as police detention facilities, penitentiary institutions, immigration detention centres, psychiatric

\footnotetext{
28 See IACHR, Resolution No. 4/2020 cit., A.

29 СРт, 'Statement of principles relating to the treatment of persons deprived of their liberty in the context of the coronavirus disease (Covid-19) pandemic' (20 March 2020) $\mathrm{CPT} / \operatorname{Inf}(2 \mathrm{O} 20) \mathbf{1 3}$.

3 WHO - Regional Office for Europe, 'Preparedness, prevention and control of covid-19 in prisons and other places of detention. Interim guidance' (15 March 2020) 1-2.

$31 \quad$ Ibid., 1.
} 
hospitals and social care homes, as well as newly established facilities/zones where persons are placed in quarantine. Importantly, the С РT pointed out that the protection of the health and safety of detained persons also contributes to preserving the health and safety of those working in such structures. ${ }^{32}$ It then recommended that States should resort, as far as possible, to alternatives to deprivation of liberty, including commutation of sentences, early release and probation, and should refrain, to the maximum extent possible, from detaining migrants. ${ }^{33}$

The CPT subsequently adopted, on 9 July 2020, a 'Follow-up statement regarding the situation of persons deprived of their liberty in the context of the ongoing COVID-19 pandemic'. This second statement takes account of the information received from the member States concerning the measures taken with respect to persons deprived of liberty. Such information revealed that during the pandemic, most member States had increased the use of non-custodial measures and taken steps to facilitate contact of detainees with the outside world, while some had limited the use of administrative detention of migrants and improved medical screening. Stressing the need for an approach based on respect for human rights, in the Follow-up Statement, the CPT concluded that COVID-19 hit hardest in places of detention where its previous recommendations had not been implemented, calling on member States to seize the opportunities generated by the emergency and to stabilize certain measures taken during the pandemic. The Committee also stressed the importance of independent monitoring of places of deprivation of liberty and, in this regard, welcomed the fact that National Preventive Mechanisms (NPM), which had interrupted their monitoring visits, had resumed such crucial activity. ${ }^{34}$

Another document of relevance is the Statement of interpretation on the right to protection of health in times of pandemic, which was issued on 21 April 2020 by the European Committee on Social Rights (ECSR). ${ }^{35}$ The ECSR is the body responsible for monitoring compliance by the States parties to the European Social Charter; through its statements of interpretation, it clarifies the scope and content of the Charter's rights.

32 СРT, Statement of principles cit., 1.

33 Ibid., 5 .

34 The designation of National Preventive Mechanisms (NPMS) to carry out visits to places of detention, to monitor the treatment of and conditions for detainees and to make recommendations regarding the prevention of ill-treatment is required by Optional Protocol to the Convention against Torture and other Cruel, Inhuman or Degrading Treatment or Punishment (opCAT, Part IV).

35 ECSR, 'Statement of interpretation on the right to protection of health in times of pandemic' (21 April 2020). 
In the said Statement, the ECSR, while endorsing many measures adopted by States in response to the pandemic, underlines that all these measures must be taken having regard to the current state of scientific knowledge and in accordance with relevant human rights standards. The Statement stresses that most of these measures are also required to protect other rights guaranteed by the European Social Charter, like the right to safe and healthy working conditions ex Art. 3 and the rights of persons with disabilities ex Art. 15, and then lists ways the ECSR will monitor States' actions, notably through the reporting and the collective complaints procedures. ${ }^{36}$

\section{Developments at the European Court of Human Rights}

\subsection{Covid-Related Developments}

On 5 November 2020, the European Court of Human Rights (ECtHR) issued its first decision related to States parties' responses to CoviD-19 in the case Le Mailloux v. France. The case concerned Mr. Le Mailloux's objections to the handling of the pandemic by the French State. The applicant, who affirmed to have been seriously weakened by a grave illness, had intervened in an application to the Conseil d'État to enjoin France to provide appropriate protective measures to health professionals and to introduce mass screening for all. Once the application was dismissed as inadmissible, the applicant turned to the ECtHR claiming that France had failed to comply with its positive obligations under Articles 2 (right to life), 3 (prohibition of torture and inhuman and degrading treatment), 8 (right to respect for private and family life) and 10 (right to freedom of expression) of the Convention. Specifically, he complained about restrictions on access to diagnostic tests, preventive measures and specific types of treatment, as well as interference in the private lives of individuals dying of the virus alone.

The Court unanimously declared the case inadmissible, as the applicant had not shown to be personally affected by the measures taken by the French State to curb the propagation of the virus among the general population. The judges reiterated that the right of individual application under Article 34 of the Convention requires that an applicant be able to claim to be a "victim" of a violation of the treaty. In other terms, since the ECH R does not permit an actio popularis, i.e., a complaint alleging a violation of the Convention in the

$36 \quad$ Ibid., 6. 
abstract, ${ }^{37}$ applicants must produce reasonable and convincing evidence of the likelihood that a violation personally affecting them will occur. ${ }^{38}$

\subsection{Climate Change-Related Developments}

The European Court has not yet made any rulings specifically about climate change. Nonetheless, in the year under review, it declared admissible two cases, so paving the way for some brand-new jurisprudence in the near future.

The first case, named 'Duarte Agostinho and Others v. Portugal and Others', was brought to the Strasbourg Court by six young people from Portugal (aged 8 to 21) against 33 States Parties for failure to adequately address the 'climate emergency'. ${ }^{39}$ The application, which was taken directly to the Court without exhausting domestic instances, alleged a violation of these States' positive obligations under Articles 2 (right to life) and 8 (right to private and family life) read in the light of the 2015 Paris Climate Agreement, the UN Framework Convention on Climate Change and the UN Convention on the Rights of the Child, as well as a violation of Article 14 (right to enjoy ECHR rights without being discriminated) on the grounds of age.

More specifically, the applicants argued that the responding States are not sufficiently reducing their greenhouse gas emissions in their territory and jurisdiction and have not assumed responsibility for their various contributions to global emissions due to the export of fossil fuels, the import of goods containing 'embodied' carbon and the emissions caused abroad by entities domiciled within their respective jurisdictions. Interestingly the ECtHR, when it asked the parties to comment on the alleged violations, also invoked motu proprio the prohibition of torture and inhuman and degrading treatment ex Article 3 ECHR and the right to property ex Article 1 of Protocol No. 1 to the Convention. While it is not uncommon for the Court to raise an issue motu proprio, it bears noting that it is the first time that the ECtHR invoked Article 3 in a climate change litigation. ${ }^{40}$

37 See ECtHR, 'Centre de ressources juridiques au nom de Valentin Câmpeanu c. Roumanie', Application No. 47848/o8, Grand Chamber (17 July 2014) para. 101.

38 See ECtHR, para. 11.

39 See ECtHR, 'Duarte Agostinho and Others/et autres - Portugal and 32 other States/et 32 autres États', Application No. 39371/20, Communication (13 November 2020) [Section IV]. The States at issue are those which are also contracting parties of the 2015 Paris Agreement.

40 See inter alia the following comments: Ole W Pedersen, 'The European Convention of Human Rights and Climate Change - Finally!' (22 September 2020) EJIL: Talk! Blog of the European Journal of International Law; Corina Heri, 'The ECtHR's Pending Climate Change Case: What's Ill-Treatment Got to Do with It?' (22 December 2020) EJIL:Talk! Blog of the European Journal of International Law. 
Recognising the 'importance and urgency of the issues raised, ${ }^{41}$ on 15 October 2020, the Court has decided to fast-track the case under Article 41 of its Statute and has established that governments should respond to both the admissibility and the substance of the case by 27 May 2021.

The second climate change case was brought to the Strasbourg Court on 26 November 2020 by a group of elderly Swiss women - Campaign group KlimaSeniorinnen Schweiz - and four individual women. ${ }^{42}$ The applicants argued that Switzerland, by failing to take the necessary measures to meet the 2030 goal set by the 2015 Paris Agreement on climate change ( $\left.\mathrm{CoP}_{21}\right)$, in particular, 'to do its share to limit the increase in the global average temperature to "well below $2^{\circ} \mathrm{C}$ " compared to pre-industrial levels, ${ }^{43}$ violated their rights under inter alia Articles 2 (right to life) and 8 (right to respect for private and family life) of the ECHR. While in the domestic litigation, the Swiss Federal Supreme Court decided that they did not fulfil the 'victim' requirement ex Article $34 \mathrm{ECHR},{ }^{44}$ they claimed, as older women, to be particularly vulnerable since their health, and hence their life, are most at risk from heat waves exacerbated by climate change. Moreover, in the application to the ECtHR, they affirmed the existence of a 'sufficient close connection' between the Swiss authorities' omissions and the risks to their life and health. ${ }^{45}$ Underlining that such a connection is not diminished by the small size of their country, they referred to the Urgenda judgement that was rendered in December 2019 by the Dutch Supreme Court. In this judgement, which is the most ground-breaking ever pronounced so far in climate change matters, the Dutch Court ruled that climate change can be subsumed under Articles 2 and $8 \mathrm{ECHR}$ due to the real and immediate risk it causes to the lives and welfare of Dutch residents. Remarkably, the Supreme Court affirmed that

[ $t$ ] he fact that this risk will only be able to materialise a few decades from now and that it will not impact specific persons or a specific group of persons but large parts of the population does not mean - contrary to the State's assertions - that Articles 2 and 8 ECHR offer no protection from

\footnotetext{
41 See ECtHR, Rules of Court, Rule 41, Strasbourg (1 January 2020) Registry of the Court.

42 See <https://klimaseniorinnen.ch/wp-content/uploads/2020/11/201126_Application _ECtHR_KlimaSeniorinnen_extract_anonymised-2.pdf $>$.

43 Ibid., 56.

44 See Schweizerisches Bundesgericht, Verein KlimaSeniorinnen Schweiz, 1C_37/2019, 5 May 2020, <https://klimaseniorinnen.ch/wp-content/uploads/2020/o5/Urteil-BGer_anonymi siert.pdf $>$.

45 See <https://klimaseniorinnen.ch/wp-content/uploads/2020/11/201126_Application _ECtHR_KlimaSeniorinnen_extract_anonymised-2.pdf $>, 38$.
} 
this threat $[\ldots]$. This is consistent with the precautionary principle $[\ldots]$. The mere existence of a sufficiently genuine possibility that this risk will materialise means that suitable measures must be taken. ${ }^{46}$

Consequently, upholding the Court of Appeal's decision, the Dutch Supreme Court confirmed that the Netherlands must reduce its emissions by the end of 2020 by at least $25 \%$ compared to 1990 .

In judging Verein KlimaSeniorinnen Schweiz and others v. Switzerland, which on 26 March 2021 was declared admissible and received priority status, the ECtHR could thus finally clarify States parties' human rights obligations in regard to climate change.

46 Dutch Supreme Court, Urgenda Foundation v. State of the Netherlands, 2o December 2019, <https://www.urgenda.nl/wp-content/uploads/ENG-Dutch-Supreme-Court-Urgend a-v-Netherlands-20-12-2019.pdf $>$ (English translation), 5.6.2. 